\title{
Circuits neuronaux et comportement / Neural
} circuits and behavior

Centre interdisciplinaire de recherche en biologie (CIRB)

\section{Alexander Fleischmann}

\section{(2) OpenEdition}

\section{Journals}

Édition électronique

URL : https://journals.openedition.org/annuaire-cdf/16133

DOI : 10.4000/annuaire-cdf. 16133

ISBN : 978-2-7226-0572-5

ISSN : 2109-9227

\section{Éditeur}

Collège de France

\section{Édition imprimée}

Date de publication : 30 décembre 2020

Pagination : 652

ISBN : 978-2-7226-0516-9

ISSN : 0069-5580

\section{Référence électronique}

Alexander Fleischmann, " Circuits neuronaux et comportement / Neural circuits and behavior », L'annuaire du Collège de France [En ligne], 118 | 2020, mis en ligne le 01 avril 2021, consulté le 22 août 2022. URL : http://journals.openedition.org/annuaire-cdf/16133; DOI : https://doi.org/10.4000/ annuaire-cdf. 16133 


\title{
CiRCUITS NEURONAUX ET COMPORTEMENT / NEURAL CIRCUITS AND BEHAVIOR
}

\author{
Responsable : Alexander FLEISCHMANN
}

\section{RECHERCHE}

Page web : https://www.college-de-france.fr/site/en-cirb/fleischmann.htm.

\section{RÔLE DES PROTÉINES MATRICIELLES DANS L'HYPOXIE ET L'ANGIOGENÈSE / ROLE OF MATRIX PROTEINS IN HYPOXIA AND ANGIOGENESIS}

\author{
Responsable : Stéphane GERMAIN
}

\section{RECHERCHE}

Page web : https://www.college-de-france.fr/site/en-cirb/germain.htm.

The sequence of biological events that permits an organism to maintain tissue viability in hypoxia remains poorly understood. Variations in oxygen concentration lead to respiratory, metabolic and vascular adaptations in tissues. How hypoxic endothelial cells (EC) integrate chemical signals with mechanical cues from their local tissue microenvironment in order to produce functional capillary networks that exhibit specialized form remains an open question. A key role of hypoxia in the regulation of many endothelial functions (Ferratge et al.) is nevertheless well established and growing evidence show that angiogenesis, defined as the events leading to blood vessels formation by sprouting or growth of preexisting vessels, can be triggered by hypoxia, both during development and in pathological conditions such as in muscle (Latroche et al.; Gitiaux et al.), in cardiovascular ischemia (Bouleti et al.; Garcia et al.) and tumors (Bousseau et al.). Our team is also interested in understanding how angiogenesis and vascular integrity are regulated in hypoxic conditions. We are also analyzing ECM composition, deposition, posttranslational modifications and rearrangement by ECs. We studied ow vascular ECM is organized and scaffolded to provide structural support for blood vessels and described how it regulates endothelial cell and pericyte functions and how it is required for proper vascular morphogenesis and maintenance of vascular homeostasis (Germain et al.; Marchand et al.).

\section{PUBLICATIONS}

Bouleti C., MonNot C. et GERMAIN S., «ANGPTL4, a multifaceted protein at the cross-talk between metabolism and cardiovascular disorders », International Journal of Cardiology, vol. 256, 2018, p. 2, DOI : 10.1016/j.ijcard.2017.10.123. 
Latroche C., Weiss-Gayet M., Muller L., Gitiaux C., Leblanc P., Liot S., BenLarbi S., Abou-Khalil R., Verger N., Bardot P., Magnan M., Chrétien F., Mounier R., Germain S. et ChAZAud B., "Coupling between myogenesis and angiogenesis during skeletal muscle regeneration is stimulated by restorative macrophages », Stem Cell Reports, vol. 9, no 6, 2017, p. 2018-2033, DOI : 10.1016/j.stemcr.2017.10.027.

Gitiaux C., Latroche C., Weiss-Gayet M., Rodero M.P., Duffy D., Bader Meunier B., Glorion C., Nusbaum P., Bodemer C., Mouchiroud G., Chelly J., Germain S., DEsGuerre I. et ChaZAud B., «Myogenic progenitor cells exhibit IFN type I-driven proangiogenic properties and molecular signature during juvenile dermatomyositis », Arthritis \& Rheumatology, vol. 70, $\mathrm{n}^{\circ}$ 1, 2018, p. 134-145, DOI : 10.1002/art.40328.

\section{ÉVOLUTION ET DÉVELOPPEMENT DES CELLULES GERMINALES / EVOLUTION AND DEVELOPMENT OF GERM CELLS}

Responsable : Jean-René HuYNH

\section{RECHERCHE}

Pages web : https://www.college-de-france.fr/site/en-cirb/huynh.htm et http://germcells.fr.

\section{Publication}

Clémot M., Molla-Herman A., Mathieu J., Huynh J.-R. et Dostatni N., «The replicative histone chaperone CAF1 is essential for the maintenance of identity and genome integrity in adult stem cells », Development, vol. 145, n 17,2018 , DOI : 10.1242/dev.161190.

\section{MODĖLES ALÉATOIRES POUR L'INFÉRENCE DE L'ÉVOLUTION DU VIVANT / STOCHASTIC MODELS FOR THE INFERENCE OF LIFE EVOLUTION (SMILE)}

Responsable : Amaury LAMBERT

\section{RECHERCHE}

Page web : https://www.college-de-france.fr/site/en-cirb/lambert.htm.

Dirigée par Amaury Lambert (professeur à Sorbonne Université), l'équipe SMILE regroupe des mathématiciens et des biologistes de l'évolution (quatre chercheurs titulaires et huit non titulaires). 